\title{
Peningkatan Pengetahuan Siswa tentang HIV/AIDS di SMAN 1 Parigi Kabupaten Pangandaran
}

\author{
Dadang Purnama ${ }^{1}$, Udin Rosidin ${ }^{2}$, Umar Sumarna ${ }^{3}$ \\ Universitas Padjadjaran, Jl. Raya Bandung - Sumedang No.KM. 21, Hegarmanah, Kec. Jatinangor, \\ Kabupaten Sumedang, Jawa Barat 453631,2,3 \\ Email: dadang.purnama2017@unpad.ac.id
}

\begin{abstract}
ABSTRAK
Indonesia merupakan salah satu negara yang memiliki kasus HIV/AIDS yang tinggi di dunia. Kelompok remaja memiliki resiko yang besar terhadap penyebaran kasus tersebut. SMAN 1 Parigi merupakan salah satu SMA yang memiliki siswa terbanyak di Pangandaran. SMA Negeri 1 Parigi sebagian besar siswa memiliki perilaku acuh pada isu HIV/AIDS, sedangkan Pangandaran merupakan kota yang memiliki tingkat HIV/AIDS yang tinggi yang seharusnya para remaja memiliki tingkat kepedulian yang tinggi pula mengenai isu tersebut. Perilaku acuh siswa tentang isu bahaya HIV/AIDS dimungkinkan karena kurangnya pengetahuan siswa tentang HIV/AIDS. Tujuan dari kegiatan pengabdian ini adalah untuk meningkatkan pengetahuan siswa SMAN 1 Parigi dalam mencegah penularan HIV/AIDS. Metode pendidikan kesehatan yang digunakan adalah dengan cara ceramah dan diskusi. Sebelum dan sesudah ceramah dilakukan pre dan post test sebagai bentuk evaluasi mengukur sejauh mana peningkatan pengetahuan siswa SMAN 1 Parigi terkait materi yang disampaikan. Hasil dari pendidikan kesehatan yang dilaksanakan adalah adanya peningkatan pengetahuan siswa tentang HIV/AIDS di SMAN I Parigi. Rata rata nilai pengetahuan siswa sebelum dilaksanakan pendidikan kesehatan adalah sebesar 6,8 point. Setelah dilakukan pendidikan kesehatan rata rata nilai pengetahuan siswa meningkat menjadi 8,7 point. Peningkatan pengetahuan tersebut merupakan dampak positif pada siswa SMAN 1 Parigi dalam pencegahan penularan HIV/AIDS. Dengan pengetahuan yang dimilikinya diharapkan siswa akan peduli kepada lingkungan tempat tinggalnya untuk mencegah penularan HIV/AIDS.
\end{abstract}

Kata Kunci : Pengetahuan; Pencegahan HIV/AIDS; Siswa SMA

\begin{abstract}
Indonesia is one of the countries with high HIV/AIDS cases in the world. Youth groups have a big risk of causing these cases. SMAN 1 Parigi is one of the high schools with the most students in Pangandaran. Most of the students at SMA Negeri 1 Parigi have an ignorant attitude towards HIV/AIDS. At the same time, Pangandaran is a city with a high HIV / AIDS rate, where teenagers should have a high level of concern about the issue. Students 'indifferent behavior about HIV/AIDS dangers is possible because of their lack of knowledge about HIV/AIDS. This service activity aims to increase SMAN 1 Parigi students' knowledge in preventing HIV/AIDS transmission. The health education method used is lectures and discussions. Before and after the lecture was conducted, pre and post-tests were carried out as a form of evaluation to measure the extent to which SMAN 1 Parigi students' increase in knowledge regarding the material presented. The health education implemented increased students' knowledge about HIV/AIDS at SMAN I Parigi. The average value of students' knowledge before implementing health education was 6.8 points. After carried out health education, the average value of students' knowledge increased to 8.7 points. This increase in knowledge positively impacts students of SMAN 1 Parigi in preventing HIV/AIDS transmission. With the knowledge they have, it is hoped that students will care about their environment to avoid HIV / AIDS transmission.
\end{abstract}

Keywords: Knowledge; HIV / AIDS Prevention; High School Students 


\section{PENDAHULUAN}

Pada era globalisasi dan modernisasi dewasa ini telah terjadi perubahan dan kemajuan di segala aspek kehidupan termasuk ilmu pengetahuan dan teknologi. Kemajuan ilmu pengetahuan dan teknologi selain berdampak pada perbaikan juga memiliki dampak yang kurang baik bagi kehidupan. Dampak kurang baik tersebut diantaranya terjadi karena sebagian orang menyikapi kemajuan ilmu pengetahuan dan teknologi dengan tidak tepat. Kondisi tersebut akan mengakibatkan masalah kesehatan seperti HIV/AIDS. Indonesia merupakan salah satu negara yang memiliki kasus HIV/AIDS yang tinggi di dunia. Data Kemenkes menunjukkan jumlah kumulatif yang dilaporkan sampai dengan Juni 2018 sebanyak 301.959 jiwa. Estimasi pada tahun 2015 sebanyak 630.147 orang yang hidup dengan HIV dan pada tahun 2020 diperkirakan ada 652.349 kasus. Hal ini menyebabkan HIV/AIDS tetap sebagai beban kesehatan masyarakat di Indonesia bahkan di dunia (Darlis dkk, 2020)

Potensi kurang baik dalam menggunakan teknologi sering terjadi pada remaja. Para remaja saat ini hampir semua memiliki gadget namun mereka tidak menggunakannya dengan bijak. Melalui gadget tersebut para remaja menonton video pornografi yang menyebabkan timbulnya rasa keingintahuan dan keinginan untuk mencobanya tanpa memikirkan dampak yang akan terjadi. Dari timbulnya keingintahuan tersebut mendorong mereka untuk melakukan adegan-adegan yang ada di dalam video. Perilaku remaja seperti itu sangat beresiko tertularnya HIV/AIDS. Berdasarkan data Kemenkes pada akhir Juni 2010 data penularan HIV/AIDS pada remaja di Jawa Barat, dari jumlah penduduk Jawa Barat yang berusia 10-24 tahun, sebesar 11.358.704 atau 26,60\% adalah remaja. Sebesar 3.147 remaja usia 15-29 tahun terkena HIV/AIDS dengan penularan terutama disebabkan melalui hubungan seks dan jarum suntik. Di Indonesia yang memiliki angka kejadian HIV/AIDS tinggi berada di Provinsi Jawa Barat salah satunya di Kabupaten Pangandaran yang merupakan kasus HIV/AIDS terbanyak keempat (Yani, 2017).

SMA Negeri 1 Parigi merupakan salah satu Sekolah Menengah Atas di Kabupaten Pangandaran. Sekolah ini memiliki siswa terbanyak diantara SMA yang ada di Kabupaten Pangandaran. SMA Negeri 1 Parigi terletak \pm 1 kilometer ke arah selatan dari pusat ibu kota Kabupaten Pangandaran dan \pm 9 Kilometer dari ibu kota Kecamatan Parigi, serta \pm 750 meter dari garis pantai selatan Samudra Indonesia. SMA Negeri 1 Parigi mulai beroperasi pada tahun pelajaran 1981-1982 dengan status kelas jauh dari SMA Negeri Banjar. Pada tahun pelajaran 1982-1983, SMA Negeri Parigi resmi berdiri dengan dasar 
Surat Keputusan Departemen P dan K No. 298/10/1982. Tanah sekolah sepenuhnya adalah milik negara. Luas area seluruhnya adalah $10.018 \mathrm{~m}^{2}$. Sekitar sekolah dikelilingi oleh pagar sepanjang 520 meter. Bangunan sekolah dan seluruh ruang kelas untuk menunjang kegiatan belajar pada umumnya dalam kondisi baik. Dengan segala fasilitas yang ada, SMA Negeri 1 Parigi kini menjadi salah satu sekolah yang unggul dalam prestasi akademik dan non akademik. Banyak penghargaan yang didapatkan oleh siswa maupun guru. Hasil penilaian Badan Akreditasi Nasional SMA Negeri 1 Parigi mendapatkan predikat A.

Dalam survei awal yang dilaksanakan pada tanggal 5 Desember 2019 oleh mahasiswa Unpad terhadap beberapa siswa SMAN 1 Parigi mendapatkan informasi bahwa di SMA Negeri 1 Parigi sebagian besar siswa memiliki perilaku acuh pada isu HIV/AIDS, padahal Pangandaran merupakan kota yang memiliki tingkat HIV/AIDS yang tinggi yang seharusnya para remaja memiliki tingkat kepedulian yang tinggi juga mengenai isu tersebut. Perilaku acuh siswa tentang isu bahaya HIV/AIDS dimungkinkan karena kurangnya pengetahuan siswa tentang HIV/AIDS. Kondisi tersebut apabila dibiarkan akan berdampak buruk terhadap kesehatan remaja di Pangandaran. Pentingnya pengetahuan siswa mengenai HIV/AIDS merupakan masalah utama yang perlu diperhatikan oleh berbagai pihak khususnya remaja karena mengingat belum ada vaksin untuk mencegah serta mengobati HIV/AIDS. Pencegahan sangat tergantung pada kesadaran masyarakat khususnya remaja. Perubahan perilaku individu dalam pencegahan HIV/AIDS juga sangat dipengaruhi oleh lingkungan. Pangandaran yang berada di pinggi pesisir pantai dan banyak dikunjungi wisatawan dalam dan luar negeri memiliki resiko tinggi dalam penularan HIV/AIDS. Wisatawan yang datang dipastikan memiliki latar belakang yang berbeda sehingga dimungkinkan adanya potensi untuk melakukan hal-hal yang menjadi faktor penyebaran HIV/AIDS. Karakteristik Kabupaten/Kota yang memiliki keunggulan tempat wisata dan mempunyai tingkat mobilitas tinggi, wisatawan mempunyai potensi untuk melakukan hubungan seksual yang tidak aman di tempat wisata (Heriana dkk, 2015). Memperhatikan hal tersebut maka hal ini menjadi tantangan bagi tim pengabdian untuk memberikan pengetahuan tentang HIV/AIDS sehingga mereka bisa menyadari pentingnya upaya pencegahan penyakit HIV/AIDS dan mengubah kebiasaan serta perilaku beresiko yang memungkinkan terkena penyakit HIV/AIDS.

Selain itu pengaruh lingkungan yang kurang baik serta mengingat Pangandaran adalah kabupaten ke-4 dengan kasus HIV/AIDS terbesar di Indonesia. Maka dengan perilaku remaja yang seperti ini dapat mempercepat penyebaran HIV/AIDS. Berdasarkan 
hal tersebut, tim pengabdian tertarik untuk melakukan pendidikan kesehatan mengenai pentingnya pengetahuan HIV AIDS pada remaja di SMAN 1 Parigi Pangandaran.

Tujuan dari kegiatan pengabdian ini yaitu untuk meningkatkan pengetahuan bagi remaja SMAN 1 Parigi dalam mencegah penularan HIV/AIDS. Pemberian pendidikan kesehatan tentang HIV/AIDS sangat perlu dilakukan bagi remaja mengingat remaja sangat rentan sekali terkena HIV/AIDS.

\section{METODE}

Metode pengabdian pada masyarakat ini diawali dengan persiapan sosial yang bertujuan untuk membangun komitmen dengan pihak sekolah tentang pentingya kegiatan pengabdian ini. Setelah disepakati tanggal pelaksanaan maka dilaksanakan kegiatan pengabdian dalam bentuk pendidikan kesehatan. Metode pendidikan kesehatan dengan cara ceramah dan diskusi. Sebelum dan sesudah dilakukan ceramah dilakukan pre dan post test sebagai bentuk evaluasi untuk mengukur sejauh mana peningkatan pengetahuan remaja SMAN 1 Parigi terkait materi yang disampaikan.

\section{HASIL, PEMBAHASAN DAN DAMPAK}

Kegiatan pengabdian dilaksanakan pada hari Jumat, tanggal 20 Desember 2019 pukul 08.00-10.00 WIB bertempat di SMAN 1 Parigi yang berlokasi di jalan Babakan Ardiyasa No 62. Media pendidikan kesehatan yang digunakan adalah proyektor dan poster. Jumlah peserta yang hadir sebanyak 55 siswa. Materi yang disampaikan bertujuan agar peserta mengetahui apa itu HIV/AIDS dan cara penularannya, dampak penyakit dalam berbagai aspek yang timbulkan dari HIV/AIDS serta memahami upaya pencegahan terhadap HIV/AIDS. Sebelum dilakukan pendidikan kesehatan terlebih dahulu dilakukan pre test. Hasil pre test menunjukan bahwa rata-rata nilai pengetahuan siswa tentang HIV/AIDS di SMAN I Parigi adalah sebesar 6,8 point. Setelah dilakukan pendidikan kesehatan rata rata nilai pengetahuan siswa meningkat menjadi 8,7 point. Peningkatan rata rata nilai pengetahuan tersebut didukung oleh antusias peserta yang tinggi dan metode pendidikan kesehatan yang tepat seperti media poster dan leaflet. Selain itu situasi lingkungan di SMAN 1 Parigi sangat kondusif serta adanya komitmen yang baik antara tim pengabdian dengan pimpinan sekolah merupakan faktor yang memperkuat adanya peningkatan pengetahuan siswa. 

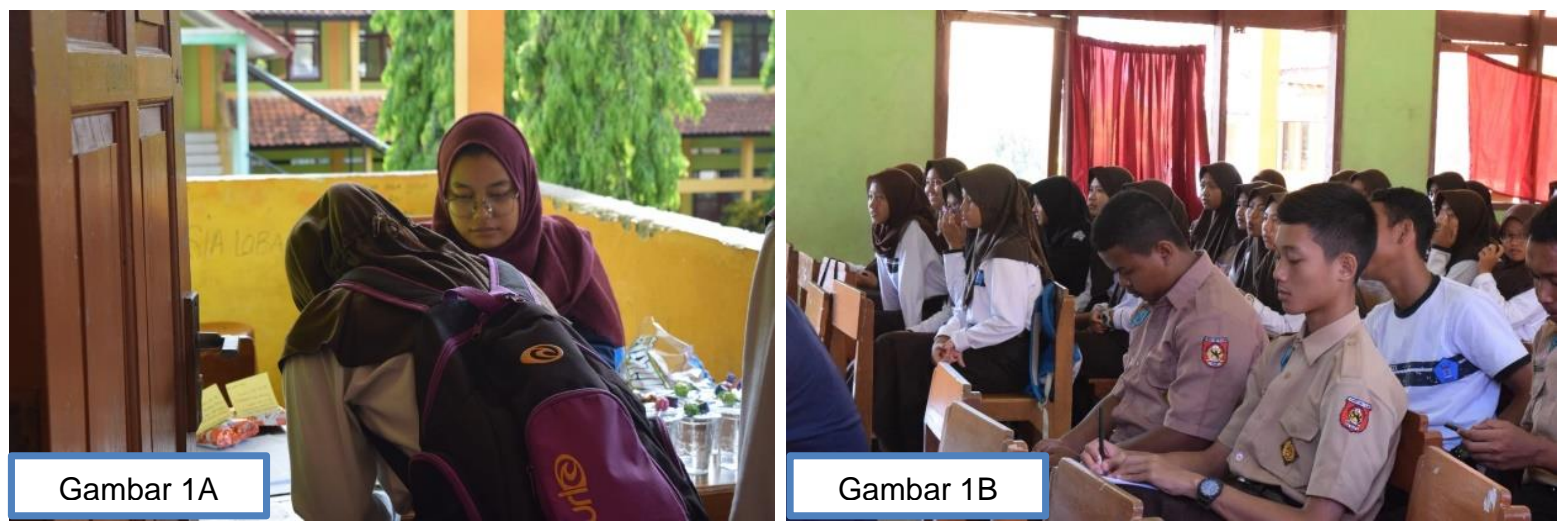

Gambar 1A. Registrasi peserta dan 1B. Peserta mengikuti kegiatan dengan antusias.

Semua peserta mengikuti kegiatan tersebut dengan antusias. Materi tentang HIV/AIDS disampaikan dengan metode ceramah dengan menggunakan media seperti poster dan leaflet. Media leaflet dan poster juga membantu peserta untuk mudah mengingat materi. Penggunaan metode dan media yang tepat dalam pendidikan kesehatan dapat membantu peserta didik dalam memahami sebuah materi (Anggraeni, 2016) Selain metode ceramah tim pengabdian ini juga juga mengunakan metode diskusi. Dalam metode ini siswa diberi kesempatan untuk mengemukakan pendapatnya terkait materi HIV/AIDS. Hal ini sesuai dengan penelitian yang dilakukan Prakoso dkk bahwa penggunaan metode ceramah, diskusi dan demontrasi sangat menentukan keberhasilan kegiatan pendidikan kesehatan (Suhendar dkk, 2020).

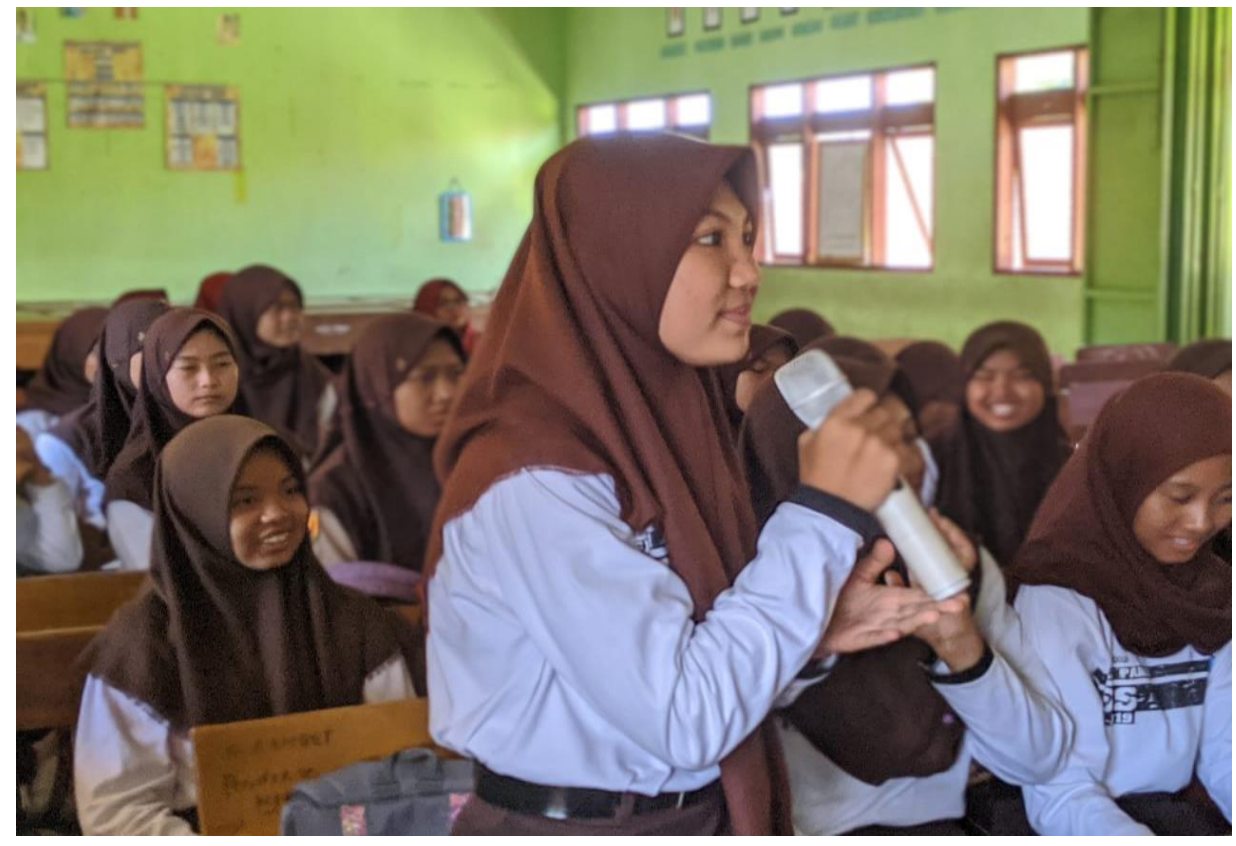

Gambar 2. Suasana Diskusi 
SMAN 1 Parigi tempat dilaksanakan pengabdian ini juga memiliki lingkungan yang sangat nyaman untuk belajar. Lingkungan tempat dilaksanakan pendidikan kesehatan ini sangat kondusif serta didukung oleh fasilitas yang telah disiapkan oleh pihak sekolah. Kegiatan pengabdian ini sangat didukung oleh unsur pimpinan di SMAN 1 Parigi. Dengan situasi dan kondisi yang sangat menunjang tersebut maka para peserta sangat fokus memperhatikan semua materi yang disampaikan. Pemaparan materi yang disampaikan pada kondisi lingkungan nyaman akan menjadi sarana pembelajaran yang sangat menguntungkan bagi peningkatan pengetahuan (Harjali, 2017).

Peningkatan pengetahuan tentang HIV/AIDS pada siswa SMAN 1 Parigi tersebut merupakan awal yang baik dalam membentuk perilaku siswa untuk pencegahan bahaya HIV/AIDS di Kabupaten Pangandaran. Perilaku pencegahan harus diawali dengan pengetahuan yang cukup. Pengetahuan merupakan faktor utama dalam pembentukan sebuah perilaku seseorang. Peningkatan pengetahuan siswa SMAN 1 Parigi tersebut dikarenakan informasi yang diberikan sesuai dengan permasalahan yang ada. Informasi yang didapat siswa dalam kegiatan ini akan berdampak pada peningkatan pengetahuannya. Hal tersebut terjadi karena informasi merupakan pemahaman yang penting untuk meningkatkan pengetahuan siswa. Menurut (Notoatmodjo, 2014) bahwa seseorang dalam memperoleh pengetahuan salah satunya bersumber dari informasi.

Memperhatikan hal tersebut upaya peningkatan pengetahuan tentang HIV/AIDS pada siswa SMAN 1 Parigi harus terus ditingkatkan berhubung daerah Pangandaran adalah daerah wisata serta mengingat Pangandaran adalah kabupaten ke-4 dengan kasus HIV/AIDS terbesar di Indonesia. Salah satu upaya peningkatan pengetahuan tersebut diantaranya adalah sebaiknya pihak sekolah bisa bekerja sama dengan tenaga kesehatan yang ada di pelayanan kesehatan terdekat. Tenaga kesehatan merupakan sumber informasi formal yang dapat memberikan pengetahuan mengenai HIV/AIDS kepada remaja. Petugas kesehatan memiliki peran sebagai pendidik. Dalam melaksanakan perannya tersebut petugas kesehatan melaksanakan bimbingan atau penyuluhan, pendidikan pada klien, keluarga, masyarakat tentang penanggulangan masalah kesehatan. Kerjasama antara SMAN 1 Parigi dengan petugas kesehatan bisa dijalankan melalui program UKS. Pelaksanaan UKS diharapkan mampu menjadi salah satu wadah dalam meningkatkan pengetahuan siswa dalam rangka membentuk perilaku hidup sehat sehingga terhindar dari masalah kesehatan (Ervina dkk, 2018). 
Banyak faktor yang akan mempengaruhi terjadinya masalah kesehatan. Salah satunya adalah faktor perilaku yang dapat diintervensi oleh pendidikan kesehatan. Dengan dilakukan pendidikan kesehatan pada siswa SMAN 1 Parigi maka pengetahuan siswa tentang HIV/AIDS meningkat dan akan berdampak positif pada perilaku siswa dalam mencegah terjadinya penularan HIV/AIDS. Menurut L Green bahwa faktor yang mempengaruhi perilaku seseorang adalah faktor Predisposing yang terdiri dari pengetahuan, sikap dan kepercayaan. Faktor Enabling yang terdiri dari sarana prasarana dan faktor Reinforcing yang terwujud dalam sikap dan perilaku tokoh (Notoatmodjo 2019).

Melihat teori tersebut adanya peningkatan pengetahuan siswa tentang HIV/AIDS di SMAN 1 Parigi merupakan dampak yang baik untuk mencegah penularan HIV/AIDS. Siswa SMA berada pada kelompok remaja yang memiliki jumlah yang besar dalam proporsi penduduk Indonesia. Jumlah remaja di Indonesia sebanyak $17 \%$ dari seluruh penduduk Indonesia. Dari jumlah yang besar ini remaja merupakan kelompok yang sangat rentan terhadap 3 resiko kesehatan reproduksi atau biasa dikenal dengan Triad KRR (Kesehatan Reproduksi Remaja) yaitu seksualitas, napza (narkotika psikotropika dll) serta HIV/AIDS (Lestary dan Sugiharti, 2011).

Pendidikan kesehatan yang dilakukan ini juga akan mengantisipasi terjadinya dampak psikologis. Biasanya penderita HIV/AIDS akan mengalami shock (goncangan batin) dimana penderita merasa bersalah, marah, dan sedih pada dirinya sendiri, penderita HIV/AIDS biasanya akan mengucilkan dan menutup dirinya sendiri karena khawatir akan menginfeksi orang lain. Pada dampak sosial, penderita HIV/AIDS akan merubah perilaku bergaul dari biasanya (anti sosial) karena merasa malu dan merasa tidak ada lagi kerabat atau orang terdekat yang mendukung serta memiliki rasa takut untuk mengungkapkannya pada orang lain (Pardita dkk, 2014). Upaya peningkatan pengetahuan siswa tentang HIV/AIDS di SMAN 1 Parigi perlu ditindaklanjuti dengan kegiatan pendidikan kesehatan kepada keluarga atau masyarakat di lingkungannya. Faktor lingkungan adalah salah satu faktor resiko yang sangat kuat dalam penularan HIV/AIDS. Seperti kebiasaan orang tua mengajarkan pendidikan seksual kepada anaknya sangat sulit dilakukan oleh semua keluarga termasuk di Pangandaran. Pendidikan seksual oleh orang tuanya masih sedikit karena dengan membicarakan hal seksual masih dianggap tabu (Prasanti dkk, 2019). 


\section{SIMPULAN}

Hasil kegiatan ini menunjukkan adanya peningkatan pengetahuan siswa SMAN 1 Parigi tentang HIV/AIDS. Pada proses pelaksanaannya siswa mengikuti kegiatan dengan baik dan aktif berpartisipasi dalam membahas materi yang disampaikan. Diharapkan dengan adanya peningkatan pengetahuan yang dicapai siswa tersebut akan berdampak pada perubahan pemahaman siswa untuk menjadi lebih peduli terhadap perilaku pencegahan HIV/AIDS. Kegiatan ini perlu dilakukan secara rutin oleh pihak sekolah dan petugas kesehatan serta ditindaklanjuti dengan pendidikan kesehatan kepada keluarga dan masyarakat di Pangandaran.

\section{UCAPAN TERIMA KASIH}

Ucapan terimakasih kepada Rektor Universitas Pajajaran, Dekan Fakultas Keperawatan Universitas Pajajaran, Kepala SMAN 1 Parigi Pangandaran, segenap mahasiswa Fakultas Keperawatan Universitas Pajajaran PSDKU Pangandaran angkatan 2018 dan pihak pihak yang sudah membantu kegiatan pengabdian masyarakat. Semoga bantuannya menjadi amal baik dan medapat balasan dari Allah SWT.. Aamiin.

\section{DAFTAR PUSTAKA}

Anggraeni, Erina Setya. 2016. "Perbedaan Pendidikan Kesehatan Metode Demonstrasi Secara Langsung Dengan Audio Visual Tentang Cuci Tangan Terhadap Praktek Dan Perilaku Cuci Tangan Pada Anak Usia Pra Sekolah.”

Darlis, Idhar, Fatmah Afrianty Gobel, and Yusriani Yusriani. 2020. "Gambaran Pengetahuan Dan Sikap Anak Buah Kapal (ABK) Terhadap Perilaku Berisiko Tertular HIV/AIDS.” In Prosiding Seminar Nasional Sinergitas Multidisiplin Ilmu Pengetahuan Dan Teknologi, , 179-82.

Ervina, Ervina, Teuku Tahlil, and Mulyadi Mulyadi. 2018. "Pelaksanaan Program Usaha Kesehatan Sekolah (UKS) Di Puskesmas.” Jurnal Ilmu Keperawatan 6(2): 11-21.

Harjali, Harjali. 2017. "Strategi Guru Dalam Membangun Lingkungan Belajar Yang Kondusif: Studi Fenomenologi Pada Kelas-Kelas Sekolah Menengah Pertama Di Ponorogo.” Jurnal Pendidikan dan Pembelajaran (JPP) 23(1): 10-19.

Heriana, Cecep, Siti Nunung Nurjannah, and Rossi Suparman. 2015. "Distribusi Spasial Dan Determinan Kejadian HIV/AIDS Di Propinsi Jawa Barat Tahun 2014.” Jurnal Ilmu Kesehatan Bhakti Husada: Health Sciences Journal 4(2): 1-10. 
Lestary, Heny, and Sugiharti Sugiharti. 2011. "Perilaku Berisiko Remaja Di Indonesia Menurut Survei Kesehatan Reproduksi Remaja Indonesia (SKRRI) Tahun 2007." Indonesian Journal of Reproductive Health 1(3): 136-44.

Notoatmodjo, Soekidjo. 2014. "Ilmu Perilaku Kesehatan Penerbit PT Rineka Cipta." _. 2019. "Promosi Kesehatan Dan Ilmu Perilaku."

Pardita, Dewa Putu Yudi, and I Ketut Sudibia. 2014. "Analisis Dampak Sosial, Ekonomi, Dan Psikologis Penderita HIV AIDS Di Kota Denpasar."

Prasanti, Ditha, Hadi Suprapto Arifin, and Ikhsan Fuady. 2019. "Sosialisasi Pencegahan Dan Penanggulangan HIV AIDS Bagi Pelajar SMA Di Kawasan Pangandaran." Jurnal Abdi MOESTOPO 2(02): 43-49.

Suhendar, Iwan, Udin Rosidin, and Nina Sumarni. 2020. "Pendidikan Kesehatan Tentang Hidup Bersih Dan Sehat Di Lembaga Kesejahteraan Sosial Anak Al-Amin Garut." JPKMI (Jurnal Pengabdian Kepada Masyarakat Indonesia) 1(3): 135-45.

Yani, Desy Indra. 2017. "Gambaran Pengetahuan Dan Sikap Tentang HIV/AIDS Pada Remaja Di Pangandaran.” Jurnal Pengabdian Kepada Masyarakat 1(1). 